\section{Puppet as a Pedagogical Tool: A Literature Review}

\author{
Tarja Kröger ${ }^{\mathrm{a},{ }^{*},}$, Anne-Maria Nupponen ${ }^{\mathrm{b}}$
}

$\begin{array}{ll}\text { Received: } & 12 \text { November } 2018 \\ \text { Revised: } \quad 27 \text { February } 2019 \\ \text { Accepted: } \quad 04 \text { March } 2019 \\ \text { ISSN: 1307-9298 } \\ \text { Copyright @ IEJEE } \\ \text { www.iejee.com }\end{array}$

DOI: 10.26822/iejee.2019450797

\begin{abstract}
This study examines the potential of puppets in the educational context. The study offers a literature review on the benefits and possibilities of the puppet as a pedagogical tool. The literature was searched using primarily an international e-material search of UEF FINNA. Additional articles were retrieved from Google Scholar and from the reference lists of selected papers. Articles were chosen and included according to specific selection criteria. Fifteen papers met the criteria and are included in the review. The review reveals five potential uses for puppets in education. These potential uses include: (1) generating communication, (2) supporting a positive classroom climate, (3) enhancing creativity, (4) fostering co-operation in and integration into a group, and (5) changing attitudes.
\end{abstract}

Keywords: Pedagogical Puppetry, Educational Methods, Elementary-Secondary Education, Literature Review

\section{Introduction}

Puppets are useful pedagogical tools, however, the potential of puppets could be more often utilized in schools. For example, Korosec (2013) reports how a number of educators in Slovenian schools have a predominantly positive attitude towards the use of puppets in classroom situations, but puppets are rarely used in the classroom. One explanation could be that teachers do not have enough knowledge of working with puppets and how these tools would be good and useful. There is relatively little comprehensive research available in English to show the significant benefits of using puppets or puppetry in education. The evidence is mainly provided through case studies, uncontrolled evaluation studies, or short educational interventions.

The purpose of this review is to systematically investigate existing evidence of the reported benefits and possibilities of using puppets in education. This review focuses on scholarly studies in the context of formal education. A synthesis is made of the findings by developing a theoretical framework within which to discuss the benefits and possibilities of puppets as pedagogical tools.

\section{Defining a puppet}

A puppet is a movable doll that a puppeteer manipulates. The body movements provide visual impressions: a puppet conveys emotions and thoughts through movement, for example, of its hands and head. A puppeteer can also give the puppet a voice. A puppet is an inanimate object that, in the hands of a puppeteer, comes to life.

Hand puppets have an open interior enabling the manipulation of them directly with one hand. Some puppets have control devices. For example, rod puppets can be manipulated with sticks, and marionettes have strings. Puppetry is a form of theatre or performance that involves the manipulation of puppets. A puppet is, in this context, an umbrella term, and in the reviewed studies, the authors do not necessarily give details about the puppets used. The focus of this article is on hand puppets and puppets manipulated with sticks or strings. Finger puppets, which are smaller than other puppets, are not included.

\section{Educational Contexts of Using Puppets}

Pedagogical studies of the use of puppets focus on how a single puppet or several puppets can be used for different purposes and in different educational contexts. The typical educational context for using hand puppets is that an educator plays a puppet theater for children. Puppet theatre as an art form is widely researched (e.g. Peltonen \& Tawast, 2009; note also e.g. https://www.unima.org/en/ and http:// www.unima.fi). A show can have an educationally important theme, for example, it can present how to handle attitudes towards disabilities (see e.g. Dunst, 2012; 2014). On the other hand, creating a puppet show together, including making the puppets, writing the script, creating the scenery, and performing the play, can be part of artistic education (see e.g. Hamre, 2012; see also special guidebooks published for this purpose, e.g. Arasmo \& Alopaeus 1992).

Puppets are also used in education without an actual theatre stage or script. For example, a teacher can use a puppet to ask children questions and discuss the questions with them. A puppet can also be a helpful tool in verifying children's understanding when they answer questions and participate in a dialogue (Remer \& Tzuriel, 2015).

In the classroom, puppets are also tools of children and youths. Pupils can create puppets, or a puppet show, or they can play spontaneously with puppets. A puppet can even be a good friend of the children (see e.g. Gobec, 2012; Korošec, 2012).

Puppets are suitable for different kind of educational contexts, from rehearsing performance and expression skills to be integrated into specific subjects (see. e.g. Fisler, 2003; Kroflin, 2012a; Lowe \& Matthew, 2000; Simon et al., 2008). Puppets can be used even to teach nanotechnology (see Brits, Potgieter, \& Potgieter, 2014). Puppets can also be

a,* Corresponding Author: Tarja Kröger, University of Eastern Finland, Finland. E-mail: tarja.kroger@uef.fi bAnne-Maria Nupponen, University of Eastern Finland, Finland. E-mail: anne.nupponen@uef.fi 
used to deal with children with special needs. Nancy Renfro (1984), looking specifically at special needs children, argues that puppets build self-worth, encourage emotional release, and provide a visual substitute for verbal deficits and a textual substitute for visual impairments. Aronoff (2005, p.120) writes about special puppets made for demonstrating mouth movements, utilized in speech therapy. He also refers to collaboration between speech therapists and puppetry.

In addition to short improvisations or planned shows, it is possible to use puppets for long-term projects. For example, Gobec (2012) has introduced a holistic model for project work with a puppet, which combines diverse purposes. For instance, a project with a puppet could take a whole year, and it could connect diverse fields, such as science, art, culture, technique, media, communication, and ecology.

\section{Methods}

This study presents hand puppets as pedagogical tools and introduces the results of a literature review. The review was driven by the following research question: What kinds of benefits and possibilities do puppets have in education?

The literature review was primarily conducted using an international e-material search of UEF FINNA, which is a search service of the University of Eastern Finland. Additional articles were retrieved from Google Scholar and from the reference lists of selected papers.

The following keywords and combinations of keywords were used: puppet* AND education; puppet* AND learning; puppet* AND teaching. The search was limited to abstracts in English. A paper was selected if the abstract was judged to deal with the research question. Explicit criteria for specifying which studies to include in the review were developed (Table 1). All papers were selected independently by two researchers. Disagreements were resolved through discussion.

Table 1. Inclusion criteria for the review

\begin{tabular}{|c|c|}
\hline Criterion type & Inclusion criteria \\
\hline Topic & $\begin{array}{l}\text { Articles must relate directly to the research } \\
\text { question above (benefits and possibilities of } \\
\text { puppets in education). }\end{array}$ \\
\hline Recency & $\begin{array}{l}\text { Articles should have been published between } \\
\qquad 2000 \text { and } 2017 .\end{array}$ \\
\hline Age-range & $\begin{array}{l}\text { Articles should relate to school-age pupils } \\
\qquad(5-18) .\end{array}$ \\
\hline Context & $\begin{array}{l}\text { Articles should relate to formal education: } \\
\text { kindergarten or preprimary or primary or } \\
\text { secondary education. }\end{array}$ \\
\hline Language & Articles should be written in English. \\
\hline Research base & $\begin{array}{l}\text { Articles must be based on empirical research } \\
\text { (either qualitative or quantitative). }\end{array}$ \\
\hline Transparency & $\begin{array}{l}\text { The methodology of the research on which } \\
\text { the article is based must be explicit (e.g. } \\
\text { sample sizes, instruments, analysis). }\end{array}$ \\
\hline
\end{tabular}

To be included in the review, papers had to include empirical evidence relating to the impacts and outcomes of puppets as an educational tool or as a strategy in formal education. For example, puppets have been used in therapy (see e.g. Aronoff, 2005) and in children's healthcare (see e.g. Tilbrook, Dwyer, Reid-Searl, \& Parson, 2017), but such articles were excluded from this review because they did not deal with formal education. To be included in the review, papers had to relate to school-age pupils (5-18); further, the terms "children" and "pupils" are used when it is referred to school-age children and youths. Inclusion criteria required that studies were peer-reviewed reports of empirical inves- tigations. Commentaries (see e.g. Belfiore, 2013) and project descriptions (see e.g. Bennett, 2002; Gobec, 2012) were not included. Duplicates and non-English language reports were excluded. Using these criteria, fifteen papers were identified as relevant to the current review. Table 2 provides a summary of papers that met the inclusion criteria.

The reviewers systematically extracted the applicable information from each study after the studies that should be included in the review had been identified. Then the reviewers made a synthesis of the studies. This step involved combining the facts extracted from the studies using qualitative analysis.

\section{Results}

Based on our review of the literature, we identified five potential uses applied extensively in educational and learning contexts. The five potential uses are presented here as the comprehensive framework of a pedagogical puppet (see Figure 1), and each potential is given theoretical support from the literature. The potential uses are (1) generating communication, (2) supporting a positive classroom climate, (3) enhancing creativity, (4) fostering co-operation in and integration into a group, and (5) changing attitudes.

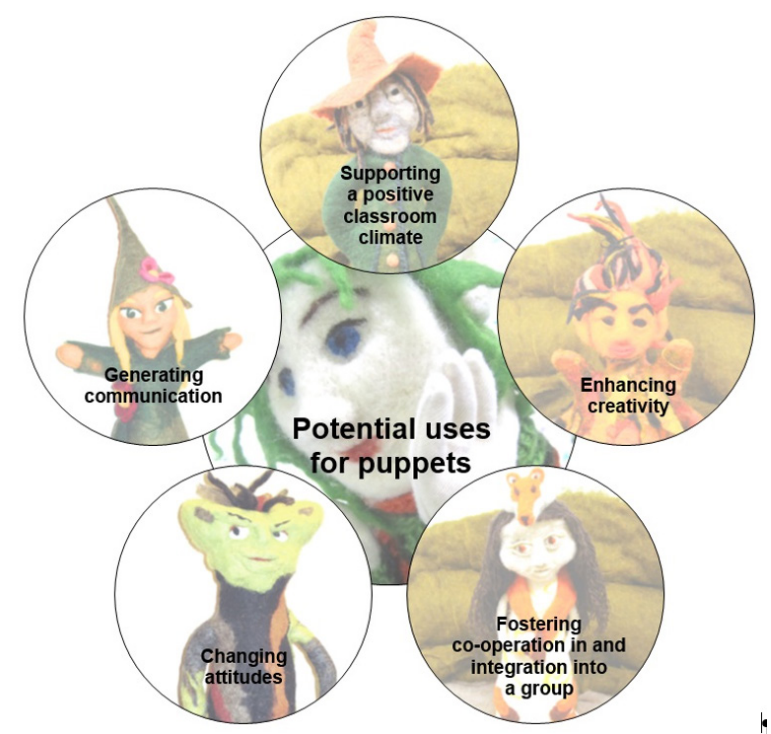

Figure 1. Potential uses for puppets. Pictures are from the website https://punomo.fi/.

\section{Generating communication}

The value of talk and communication in children's learning has been acknowledged since Vygotsky's (1962) work on language and social interaction. In the school context, there is communication between teacher and pupil(s), as well as between children and between teachers. Communication not only represents the transfer of information; it represents the establishment of a relationship with the person to whom we wish to transfer the information.

Eleven studies in the data set (Ahlcrona, 2012; Brédikytè, 2002; Çağanağa \& Kalmış, 2015; Hackling, Smith, \& Murcia, 2011; Keogh, Naylor, Maloney, \& Simon, 2008; Korošec, 2012; Korošec, 2013; Maharani, 2016; Moriguchi, Sakata, Ishibashi, \& Ishikawa, 2015; Remer \& Tzuriel, 2015; Simon, Naylor, Keogh, Maloney, \& Downing, 2008) highlight a puppet's potential to generate communication. Puppets help (1) increase and improve classroom talk, (2) increase communication by creating a favourable, relaxed atmosphere, and (3) establish teacher-student interaction and children's mutual interaction. We will treat these benefits in detail with help of data from literature below. 
Table 2. Summary of literature review

\begin{tabular}{|c|c|c|c|}
\hline Authors and year & Research method & Main outcome & Environment \\
\hline Ahlcrona 2012 & $\begin{array}{c}\text { Ethnographic approach: written } \\
\text { observations, conversations, } \\
\text { photographs, and children's } \\
\text { drawings }\end{array}$ & $\begin{array}{l}\text { The puppet is a mediating tool for children's } \\
\text { communication and learning. }\end{array}$ & $\begin{array}{l}\text { Preschool } \\
\text { education in } \\
\text { Sweden }\end{array}$ \\
\hline Brèdikytè 2002 & $\begin{array}{l}\text { Educational experiment: video- } \\
\text { taped material, observation }\end{array}$ & $\begin{array}{c}\text { Dialogical drama with pup-pets (DDP method) } \\
\text { promotes the child's creative self-expression, } \\
\text { encourages the child's independent dramatic } \\
\text { play, and stimulates verbal activity and creativity } \\
\text { along-side. }\end{array}$ & $\begin{array}{l}\text { Preschool } \\
\text { education in } \\
\text { Lithuania }\end{array}$ \\
\hline $\begin{array}{l}\text { Çağanağa and Kalmış } \\
2015\end{array}$ & $\begin{array}{l}\text { Case study: observation and } \\
\text { interviews }\end{array}$ & $\begin{array}{c}\text { Puppets are engaging and motivating in English } \\
\text { language learning. }\end{array}$ & $\begin{array}{l}\text { Kindergarten } \\
\text { (pre-school } \\
\text { learners) in Cyprus }\end{array}$ \\
\hline Dunst 2012 & $\begin{array}{l}\text { Intervention and control group } \\
\text { design }\end{array}$ & $\begin{array}{l}\text { Puppetry can improve knowledge and change } \\
\text { attitudes toward persons with disabilities. }\end{array}$ & $\begin{array}{l}\text { Elementary school } \\
\text { students } \\
\text { in USA }\end{array}$ \\
\hline $\begin{array}{l}\text { Hackling, Smith and } \\
\text { Murcia } 2011\end{array}$ & $\begin{array}{l}\text { Participatory action research } \\
\text { and design-based research } \\
\text { collaboration: video record-ings, } \\
\text { a questionnaire, field notes, and } \\
\text { inter-views }\end{array}$ & $\begin{array}{l}\text { Puppets have a positive impact on student en- } \\
\text { gagement and talk in science lessons. }\end{array}$ & $\begin{array}{l}\text { Primary school in } \\
\text { Australia }\end{array}$ \\
\hline $\begin{array}{l}\text { Keogh, Naylor, } \\
\text { Maloney and Simon } \\
2008\end{array}$ & Case study & $\begin{array}{l}\text { Puppets have a positive impact on children's } \\
\text { engagement and motivation in science lessons. }\end{array}$ & $\begin{array}{l}\text { Primary school } \\
\text { in UK }\end{array}$ \\
\hline Korošec 2012 & $\begin{array}{l}\text { Qualitative interpretative re- } \\
\text { search: essays by teachers }\end{array}$ & $\begin{array}{l}\text { The puppet is a medium for communication and } \\
\text { personal interaction. }\end{array}$ & $\begin{array}{l}\text { Primary school in } \\
\text { Slovenia }\end{array}$ \\
\hline $\begin{array}{l}\text { Mehrotra, Khunyakari, } \\
\text { Natarajan and Chun- } \\
\quad \text { awala } 2007\end{array}$ & $\begin{array}{l}\text { The design-make-appraise } \\
\text { (DMA) approach: observations, } \\
\text { field notes, videotapes, and } \\
\text { student writings }\end{array}$ & $\begin{array}{l}\text { The design and technology unit on puppetry can } \\
\text { engage students in collaborative learning. }\end{array}$ & $\begin{array}{l}\text { Middle school stu- } \\
\text { dents in India }\end{array}$ \\
\hline $\begin{array}{l}\text { Moriguchi, Sa-kata, } \\
\text { Ishibashi and Ishikawa } \\
2015\end{array}$ & $\begin{array}{l}\text { Intervention and control group } \\
\text { design }\end{array}$ & $\begin{array}{c}\text { Interaction with a doll or a puppet may have a } \\
\text { significant impact on the development of execu- } \\
\text { tive function. }\end{array}$ & $\begin{array}{l}\text { 3- to 5-year-old chil- } \\
\text { dren in pre-school } \\
\text { in Japan }\end{array}$ \\
\hline $\begin{array}{l}\text { Remer and Tzuriel } \\
2015\end{array}$ & $\begin{array}{l}\text { Intervention: semi-structured } \\
\text { interview }\end{array}$ & $\begin{array}{l}\text { A puppet is a mediating tool that increases inter- } \\
\text { est and motivation in learning. }\end{array}$ & $\begin{array}{l}\text { Kindergarten in } \\
\text { Israel }\end{array}$ \\
\hline $\begin{array}{l}\text { Simon, Naylor, Keogh, } \\
\text { Maloney and Downing } \\
2008\end{array}$ & $\begin{array}{l}\text { Mixture of research methods: } \\
\text { classroom observation, teacher } \\
\text { and pupil interviews, and teach- } \\
\text { ers' reflective diaries }\end{array}$ & $\begin{array}{l}\text { The use of puppets promotes engagement and } \\
\text { talk in science. }\end{array}$ & $\begin{array}{l}\text { Children aged 7-11 } \\
\text { in schools in UK }\end{array}$ \\
\hline Whiteland 2016 & Mixed methods case study & $\begin{array}{l}\text { Puppet-making project together with older adults } \\
\text { helps children construct new mean-ing in their } \\
\text { understanding of aging and older adults. }\end{array}$ & $\begin{array}{l}\text { Elementary class- } \\
\text { room in USA }\end{array}$ \\
\hline
\end{tabular}

Puppets help teachers improve classroom talk. In the study by Simon, Naylor, Keogh, Maloney and Downing (2008), puppets were used in science lessons where a puppet had a problem that needed to be solved. When teachers used puppets, they were more likely to ask open, thought-provoking questions, which created opportunities for the children to talk. The study contrasted this with conventional science lessons, which were more dominated by recall questions. The use of puppets enabled the teachers to become more dialogic in their science teaching and introducing puppets into the classroom influenced some fundamental aspects of their pedagogy. Several teachers noted how the children were fond of answering the puppet's questions and expressing their thoughts. Puppets also fascinated those children who tended to remain aloof: "Many of the children who would not normally contribute to a discussion took a more proactive role" (Simon et al., 2008, p. 1243).
Hackling, Smith, and Murcia (2011) examined a puppet project and enhancing classroom discourse in primary science. Their findings are consistent with the research of Simon, Naylor, Keogh, Maloney and Downing (2008). In Hackling's et al. (2011) study, most teachers noted that puppets had a positive impact on student engagement and talk. Teachers indicated that increased numbers of students participated in discussions, and students explained things more thoroughly to the puppet than to a teacher (Hackling et al., 2011).

Keogh's, Naylor's, Maloney's, and Simon's (2008) study also had primary science lessons as the context, and it gives evidence of how the role of the puppet can help in generating communication. With a puppet in hand, a teacher can act ignorant: 
The children empathised with the puppet. They understood the problem that the puppet had, and they felt sorry for the puppet because it had the problem. [...] They worked hard to articulate and explain their ideas to the puppet (who doesn't understand), rather than for the teacher (who 'knows all the answers and will know what they mean even if they don't explain well'). (Keogh et al., 2008, p. 146.)

Keogh et al. (2008) note how a puppet does not have the same status and authorship as a teacher, instead, it is viewed as a peer. A puppet acting as "the least knowledgeable member of the class" also helps children who are not confident enough to talk about their ideas; they are more comfortable talking to a puppet who does not know as much as they do. This increases communication in the classroom (Keogh et al., 2008). Simon et al. (2008) also report on puppets creating confidence. The puppet is regarded more as an equal, and it is less judgmental than the teacher is. Thus, it is easier to talk to a puppet (Simon et al., 2008).

Remer and Tzuriel (2015) report how puppets help to broaden a discussion. When a puppet is used to bring personal examples and experiences to a discussion, children are encouraged to add their examples and experiences. Remer and Tzuriel (2015) also note how a puppet can act as a role model that teaches how to ask questions and to answer with explanations.

A puppet's ability to help children relax generates communication. Çağanağa and Kalmiş (2015) note that puppets can help in developing communicative skills especially because children feel more relaxed when they talk with a puppet than with a teacher. Çağanağa and Kalmiş $(2015$, p. 8) write: “...the enjoyable atmosphere that the puppets create breaks down the barriers between the teacher and the children." Korošec (2012, p. 34) also notes the relation between relief and easy communication: "A puppet in the hands of a teacher seems to give relief. The child is relieved of his/her fear of authority and can easily establish contact with the environment."

Maharani (2016) has compared Puppet media and Picture media in teaching speaking English. The findings reveal how using puppets is more effective than using Picture media in teaching speaking because puppets are able to make students feel relaxed. Maharani (2016, p. 113) writes: “By using a puppet, students become less inhibited when they are hidden behind the puppet by only handling it to move. The puppet is an ideal springboard for developing speaking skills."

Puppets are useful in establishing a teacher-student interaction. Korošec (2012) uses the notion "indirect communication" to describe a teacher who addresses students through a puppet. The teachers noted that puppets were a helpful tool in establishing contact with children and, in addition, improving their mutual communication (see also Korošec, 2013). The puppet's ability to attract and inspire children made the communication and transfer of information easier. Puppets also helped establish spontaneous communication between students. An important finding is that the puppet is a helpful tool in including shy children in communication (Korošec, 2012, p. 39-40): "For a shy child, the puppet represents protection from direct exposure and makes it easier for him/her to get spontaneously included into the activity." In addition, Korošec (2012) notes how puppets help children with learning and speaking difficulties to participate in communication.

According to Ahlcrona (2012), a puppet can work as a "mediating tool" in communication between children and adults. Ahlcrona (2012, p. 180) explains it in the following way: "It was found that children interacting with the puppet communicated knowledge from different social practices and reflected their own experiences and perceptions against a background of impressions from media, literature and everyday life." Ahlcrona (2012) also describes a puppet's potential to generate unexpected discussion:
While conversations between the children and the puppet could take unexpected directions and twists, children initiated and controlled the content in a way that was not usual in other "normal" conversations. Such situations represent a way of making room for children's voices and creating the opportunity for using language and communication in unusual and unexpected ways [...]. (Ahlcrona, 2012, p. 181.)

According to Remer and Tzuriel (2015, p. 362-363) a teacher can use a different language, which has a positive affect on communication: "The puppet allowed for direct communication with the children - mediators reported that the fact the puppet portrayed the persona of a little girl allowed them to speak through her and use childish language, and in this manner, created a form of direct 'eye to eye' communication." Simon et al. (2008, p. 1244) also note the puppet's possibility to use a certain kind of language that affects communication positively: "Children felt that science lessons were easier to understand for a variety of reasons; the puppets used simpler language than the teacher; the puppets spoke more slowly and explained more clearly; [...]."

Brèdikytè (2002) introduces the DDP (Dialogical Drama with Puppets) method in promoting a child-teacher interaction. In the DDP method, puppets are incorporated into the presentation of a fairy tale. Puppets and the fairy tale are employed, among others, to stimulate the children's independent creativity. The teacher maintains a dialogue, and thus engages the children. The DDP method is a dialogue-based model in which the child and the teacher act as partners and build together a joint virtual reality. Brèdikytè (2002) describes it as "a new type of pedagogical interaction based on dialogue." It requires successful child-teacher interaction;

Participating in the presentation [of a fairy-tale] together with the teacher, the child as if "prepares himself" and "learns" how to replay it on his own. It is also asserted that any form of the child's active involvement and participation in a fairy-tale presentation leads him to its further replaying. Therefore, the teacher's ability to establish individual contact with every child during the presentation is absolutely vital. (Brédikytè, 2002, p. 39.)

Remer and Tzuriel (2015) and Korošec (2012) report that puppets have benefits in testing situations by helping children reveal their knowledge.

Teachers use puppet activities to test the knowledge of children, without the children being aware of that. We know that fear of exposure often prevents children from revealing all their knowledge. Indirect communication with the puppet makes knowledge-testing easier. What is more, flexible teachers can test children's knowledge in informal and playful situations with puppets. When children prepare a scene connected to a certain topic, they will include all their knowledge and experiences from that field. (Korošec, 2012, p. 36.)

\section{Supporting positive classroom climate}

The climate of a classroom has different dimensions. Evans et al. (2009) present three differentiable components of the classroom climate: academic (pedagogical and curricular elements of the learning environment), management (discipline styles for maintaining order), and an emotional component (affective interactions within the classroom). The emotional atmosphere includes psychological (level of an individual) and social (level of a community) dimensions (see Hannula 2011; Laine et al., 2015). The psychological dimension of the emotional atmosphere (level of an individual) looks at the individual experiences that occur in the class, such as emotions, thoughts, goals, beliefs, values, and motivational orientations (Hannula, 2011; Laine et al., 2015).

Ten studies in the data set (Ahlcrona, 2012; Çağanağa and Kalmış, 2015; Fisler, 2003; Hackling, Smith, \& Murcia 2011; Keogh, Naylor, Maloney, \& Simon 2008; Korošec 2012; 2013; Maharani 2016; Remer \& Tzuriel, 2015; Simon, Naylor, Keogh, Maloney \& Downing 2008) bring forward puppets' po- 
tential to support a positive classroom climate. The data shows how puppets are helpful tools especially in two dimensions (see Evans et al. 2009): in classroom management and in supporting a positive emotional atmosphere on an individual level, such as in increasing motivation.

Several studies (Çağanağa \& Kalmış, 2015; Fisler, 2003; Keogh et al., 2008; Korošec, 2012; Maharani, 2016; Remer \& Tzuriel, 2015; Simon et al., 2008) refer to the puppets potential to generate motivation, interest, and attention. For example, Keogh et al. (2008, p. 146) report about the benefit of puppets in generating motivation and interest in primary science lessons. A puppet with a problem generates motivation: "...children were highly engaged by their conversations with the puppet, motivated to solve the problem presented by the puppet, and eager to let the puppet know what they had found out." Fisler (2003) describes how a puppet theatre can provide an enjoyable way to encourage the development of reading skills:

Evidence of reading development accompanied evidence of excitement and interest in reading as a creative act. The students [in elementary school] participated in activities combining these goals with the pleasures of making puppet theatre, as well as the opportunity to engage mathematical, visual art, oratorical, and movement skills, with consideration of issues of identity construction in literary and, subsequently, performative representation. (Fisler, 2003, p. 36.)

In Remer's and Tzuriel's (2015, p. 362) study, the puppet's ability to generate interest, attention, and motivation in the children was the most frequently mentioned contribution of the puppet: "From their [the mediators'] description, it was apparent that the interest, attention and motivation of children are intertwined. The effect of the puppet on one of the factors, for the most part interest, instantly raised the others - attention and motivation." Maharani's (2016, p. 122) study reveals that puppet media is motivating because it is something new for students: “[...] since puppet media is a new media for the students, the unique interesting and joyful learning experience of puppet media make them more enthusiastic in the classroom activities than monotonous learning media they used to be using."

In Çağanağa's and Kalmış's (2015) study, teachers describe how puppets attract interest. Children are eager to participate in the lessons, and in the enjoyable environment the learning is easy. Puppets make the children concentrate, which is helpful for the teachers. Korošec (2012, p. 42-43) describes the connection between generating motivation and attention in the following way:

The puppet takes them [children] over and they focus all their attention on communicating with it. Teachers are surprised by the role of the puppet, as it supersedes their authority. The animated puppet draws the attention of children, who are willing to do the work carefully and quickly for the puppet. (Korošec, 2012, p. 42-43.)

In addition to motivating students, a puppet supports a positive emotional atmosphere with its ability to relax students and help them participate. Korošec (2012) writes that the puppet is a working partner that creates a special atmosphere in the classroom by relaxing the children (see also Korošec, 2013), releasing tension, and including every child in the work. A puppet has an important role in the classroom. Korošec (2012, p. 34) describes a puppet that accompanies children throughout the year:

Children confide in the puppet, have relaxed conversations with it, they want to touch it and stroke it. They accept the puppet as a live member of their group; they admire it and include it actively in their work. The puppet emotionally overwhelms children; it is their confidante and their ally. (Korošec, 2012, p. 34.)
The confidence of teachers can also benefit from using puppets. In Remer's and Tzuriel's (2015) study, mediators describe puppets helping them to raise their own self-confidence; a teacher can also use the puppet "as a type of cover."

A puppet can provide an alternative attitude towards mistakes. Children are less embarrassed when they do not know something if they have a puppet in hand; a puppet that makes a mistake is funny (Korošec, 2012; see also Simon et al., 2008). Keogh et al. (2008) note how a puppet can be the one who knows the least in the classroom. Children who might be unsure about sharing their ideas can feel it more comfortable to participate when there is a puppet who does not know as much as they do (Simon et al., 2008).

A puppet can be a helpful tool when there is a need for creating a comfortable atmosphere quickly. Keogh et al. (2008) remark how there is "an adjustment period" when a new teacher meets the children for the first time and before the relationship has been developed. When a puppet is used, the adjustment period can be remarkably shorter, and engagement can be generated quicker (Keogh et al., 2008). Korošec (2012) also notes how a puppet can make the first meeting easier and help establish contact.

In addition to creating a relaxed atmosphere, puppets can make lessons fun (Korošec, 2012). Remer and Tzuriel (2015) report how puppets are able to add humor and create "a playful atmosphere." In their study, the mediators describe how the puppets influence creating a cheerful atmosphere in the group and making children laugh a lot. In Simon's et al. (2008) study, children commented on having fun with puppets: enjoyment and engagement were seen to have a strong connection in many interviews.

A puppet can provide a lookout on children's feelings. Korošec (2012) notes how a puppet can be a teacher's tool in getting to know the children and establishing individual relationships with them. When children express their feelings through puppet activities, the puppet enables the teacher to notice such feelings and experiences that would have gone unrecognized. Negative emotions can be expressed with a puppet in an acceptable way (Korošec, 2012). Korošec (2012) describes how a puppet can transmit children's feelings and thoughts:

Such children [shy and unconfident and those who regularly disturb lessons] often show their skills and express their emotions in puppet play but not in direct communication. Puppets sensitise the teacher to noticing the individual emotions and characteristics of children, which would be impossible during classic lessons. [...] Children use symbolic play with the puppet that is not dictated by text or the teacher, to solve real life conflict situations on a symbolic level. Children can thereby communicate their problems to the teacher and resolve their frustration in a fictitious situation. If the teacher is included in the child's play as one of the characters, she can observe and get to know the child from a different perspective. (Korošec, 2012, p. 43, 44.)

Puppets help establish good behavior and are a helpful tool in class management. In Korošec's (2012) study, teachers note how puppets help decrease discipline problems. They report that the children are less aggressive. Puppets made even those children participate who tend to disturb lessons (Korošec, 2012.) In Çağanağa's and Kalmış's (2015) study, teachers report how a puppet can be used as "a classroom management tool." When the teacher does not manipulate the puppet, it can be put in a place where the children can clearly see it; the puppet can watch the class with the purpose of creating silence in the classroom. (Çağanağa \& Kalmış, 2015.) In Simon's et al. (2008) study, three teachers note how the puppets improve behaviour; a puppet looking out for good behaviour is a helpful tool. 
In Remer's and Tzuriel's (2015) study too, mediators report that the puppet helps maintain rules of behavior. It was noted in that study how the puppet did not have to directly comment on misbehavior; it could just have a role in monitoring. Remer and Tzuriel (2015, p. 363) write:

This role was carried out in two ways: firstly, in a preventative manner by creating an interesting learning atmosphere for the children, raising the attention level and decreasing the disruptions, and secondly, in an indirect manner, when the puppet told about her proper behavior in her kindergarten. (Remer \& Tzuriel, 2015, p. 363.)

\section{Enhancing Creativity}

Puppets have potential in strengthening creativity. According to Jean Piaget's (1962) theory, puppet play helps students develop creative skills and cognitive skills by forcing them to use their imaginations. They make up the roles, the rules, the situations, and the solutions. They have to listen and understand the information before they transcode and use it to deliver in puppet play. In the data set, four studies (Ahlcrona, 2012; Brèdikytè 2002; Korošec, 2012; 2013) highlight the potential of puppets to encourage creativity.

Korošec $(2012 ; 2013)$ reports that preschool/primary teachers see puppet activity as a possibility for creative expression. Puppet activities challenge children and provide a possibility for them to express themselves creatively.

Ahlcrona (2012) reports about children's ability to create something new when they play with a puppet. Playing with puppets may enable children "to overstep the boundaries between the 'actual' and the 'imagined' world," enhancing creative dialogues. Although current issues of today usually provide the topics for activities, puppets also inspire students to imagine the future (Ahlcrona, 2012, p. 181): "[...] by overstepping the limits of the possible and imagined worlds, puppets also generate visions of a potential future." Ahlcrona $(2012$, p. 181) describes the possibilities of puppets: "During the time of my research, the children expressed how they imagined that the puppet thought, felt, knew, understood, learned, and had ideas and skills, indicating their interest in the mental processes and abstract thinking of other people."

With help of puppets, it is possible to create an environment that supports students' creativity. Brédikyte (2002) reports that the DDP (dialogical drama with puppets) method in the pre-school classroom creates an environment that promotes the child's creative self-expression. The DDP method contributes to the child's independent dramatic play and broadens the contents and forms of playing. In addition, it stimulates verbal activity and creativity when children make up their own stories and fairy-tales. Breddikytè (2002) describes the puppet as a tool of expression and creativity:

Drama with puppets helps preschoolers, with the assistance of moving puppets, to express and show things, which cannot be expressed or shown only through verbal mediums. Thus, for the children of the age in question puppets become an additional means of self-expression, helping them better understand and express their ideas and actions. (Brédikytè, 2002, p. 43.)

\section{Fostering co-operation within and integration into a group}

Puppets and puppetry have the potential to help students integrate into a group and learn how to work cooperatively. In the data set, four studies (Korosec, 2012; 2013; Mehrotra, Khunyakari, Natarajan, \& Chunawala, 2007; Remer \& Tzuriel, 2015) highlight co-operation within and integration into a group.

Korošec (2012) notes how "[s]ilent and shy children, showoffs, hyperactive and lonely children" need special support, and how direct communication with them may be unsuc- cessful, leading to rejection. Inclusion into the group can cause difficulties. Here, a puppet can be a helpful tool (Korošec, 2012).

The puppet is a medium which helps the teacher with the integration of individuals into the group. It works as a medium for relaxation and release of tension. When the puppet is being created (if the teacher has a creative and open approach), the child feels accepted and can prove himself/herself in his/ her own way. In this way, the child can find his/her place in the group. (Korošec, 2012, p. 39.)

In her other study, Korošec (2013) reports on the effect of puppets in socialization. The puppet's important influence on socialization in a class is clearly recognized in the data. When children create puppets and play with them, they become more self-confident. As a result, schoolmates of these children start to appreciate and accept them after their success. (Korošec, 2013.)

In Remer's and Tzuriel's (2015) data, most of the mediators (84\%) noted that all the class cooperated with the puppet and regarded it as a group member. Puppets also fascinated the children considered quiet and introverted. Cooperation with the puppet helped them participate (Remer \& Tzuriel, 2015).

Mehrotra, Khunyakari, Natarajan, and Chunawala (2007) report on the trials of a Design and Technology (D\&T) unit carried out in Indian middle schools in different sociocultural settings with a focus on collaborative learning. The design and technology unit includes a unit on puppetry, which involves making a puppet and staging a puppet-show. The focus is on the potential of a design and technology unit to provide collaborative learning situations, that is, puppetry is not in focus, but it is a context for a design and technology task. However, the criteria for choosing puppetry is connected to co-operation (Mehrotha et. al., 2007, p. 3): “Each group had to make a puppet and all the puppets made by them were needed to put on the show, thus involving a second level of collaboration, with the entire cluster collaborating." The report shows that the unit on puppetry worked well as a context for cooperation in design and technology. For example, the data also showed how the task accomplished "informal role-adoption" when students adopted different roles within and across groups. Overall, Mehrotha et al. (2007) note how participating in a D\&T unit has a great significance.

As collaboration is not a regular practice in the Indian classrooms, we initially found it difficult in the trials to get students to work in groups to achieve a common goal. The D\&T unit on puppetry was so designed as to encourage students to investigate, analyze, synthesize, and evaluate ideas in groups. [...] The unit on puppetry was a D\&T unit planned not only to appeal to Grade 6 students from different regions and girls as well as boys but also to engage them in collaborative learning. The inclusive and collaborative nature of the unit is appropriate for the multicultural Indian context. (Mehrotha et al., 2007, p. 10.)

\section{Changing Attitudes}

Puppets and puppetry have potential in changing attitudes when a puppet helps a child take a new perspective on a situation. In the data set, two studies (Dunst, 2012; Whiteland, 2016) bring forward puppets' potential to change attitudes. Whiteland (2016) has investigated how attitudes may change when older adults and children participate in an intergenerational art project in which they created hand puppets, wrote scripts, and dramatized stories. Based on the statistical analysis, the data did not show any significant change in the students' attitudes toward older adults and aging. However, there was evidence that students constructed new meaning in their understanding of this topic. Overall, the intergenerational puppet-making workshop was a mutually beneficial experience. (Whiteland, 2016.) 
Dunst (2012; see also 2014) reports about changing attitudes toward and knowledge of individuals with disabilities: puppet shows provide an effective intervention among elementary students. Dunst (2012, p. 455) describes the benefits of puppetry: "What is perhaps most encouraging is the fact that such a simple intervention had discernable positive effect, and that the intervention could be delivered to a larger number of students on a single occasion."

\section{Discussion and Conclusion}

Puppets have been used in education, but systematic studies that assess and evaluate their impact on learning and teaching are in the infancy stage. We conducted a review of the literature on puppets in education and identified five potential uses that were mentioned in scholarly articles. The potential uses are (1) generating communication, (2) supporting positive classroom climate, (3) enhancing creativity, (4) fostering co-operation in and integration into a group, and (5) changing attitudes.

One study (Korošec, 2012) reports that puppets help in memorising poems. However, that was not a main finding, and no other studies report on the puppet's potential in helping memorisation, and for this reason, this finding was not included in our potential uses.

The data consists of scholarly articles. An overview on pedagogical, non-scholarly articles supports the findings. For example, the puppet's potential to generate communication has been identified in pedagogical studies (see e.g. Belfiore, 2013; Gobec, 2012), and puppets are noted as a helpful tool to include shy children in communication (see e.g. Belfiore, 2013; Kroflin, 2012a; Majaron, 2002). Many educators have also reported that the use of puppets in classrooms makes the children feel more engaged and motivated (see e.g. Debouny, 2002; Gobec, 2012; Kroflin, 2012b; Lowe \& Matthew, 2000). Not only articles but also books introduce the benefits and possibilities of puppets as pedagogical tools (see e.g. Torén, 1999; Taras-Vaulasvirta, 2003) and focus on giving instructions on how to use puppets (see e.g. Arasmo \& Alopaeus, 1992). Obviously, non-scholarly articles or books do not include data or exact methodology. However, pedagogical studies, many of them based on the author's (teacher's) own experiences, are useful tools for teachers using puppets and searching for new teaching ideas or a background for using puppets.

Puppets certainly have benefits in education. However, children may also have reservations about using puppets (see e.g. Simon et al., 2008); teachers should take this in account. In addition, it must be noted that the novelty of using puppets may increase children's interest. Çağanağa and Kalmış (2015) report how using the same puppet for too long bores children. The children lose interest when they already know what is expected to happen.

Correspondingly, not all teachers automatically benefit from using puppets. For example, Hackling et al. (2011) report on teachers who do not feel confident using puppets and engaging students in learning. Difficulties occurred, for example, in transitioning between puppet and teacher talk and developing personas for the puppets. In Remer's and Tzuriel's (2015) study, 11\% of the mediators reported that they did not always enjoy working with a puppet.

Papers selected for this review were very diverse in terms of the aims of the research, the underlying theoretical frameworks, and the methodologies used. This diversity reflects the interdisciplinarity character of the area, the varied backgrounds of the researchers, and their wide-ranging interests in puppets. The five themes developed in the current study, looking at potential uses of puppets, helped to provide a framework for organizing and understanding the use of puppets in education. To be applied most effectively in education, potential uses should not be considered solely as independent themes. In contrast, the potential uses should be viewed as complicating meanings rather than simplifying them. At times, it may even be difficult to describe one use without mentioning how it might be layered with another. For example, puppets have potential in supporting a positive classroom climate, and simultaneously, they also generate communication by creating a relaxed atmosphere.

The most notable point of the current review was the diversity of research on the positive impacts and outcomes associated with puppets. The potential uses for puppets in education identified in this article are by no means new, nevertheless, they represent largely untapped resources. The frame presented herein might prompt the more active integration of puppets into education. We suggest that a puppet should be seen as a pedagogical tool in its own right and not merely as a medium.

The potential uses of puppets proposed in the present study not only provide a framework for organizing these diverse outcomes and impacts of using puppets, but they also highlight the persistent difficulties associated with classifying learning outcomes. While empirical evidence concerning the potential of using puppets was found in the current review, there is need for more research to provide more rigorous evidence of effectiveness of the puppets. More studies would also help extend our understanding of the nature of engagement in using puppets. To encourage the use of puppets in learning, it is essential to develop a better understanding of the tasks, activities, skills, and operations that different kinds of puppets can offer and examine how these might match desired learning outcomes. As with other educational interventions, it is also important to consider how puppets are integrated into a student's learning experience.

The current review has limitations. It was limited by the search terms used, the journals included, and the time period of papers published. However, the papers discussed in this literature review provide a snapshot of the empirical research on the outcomes and impacts of puppets that is representative of the state of the art at the time of publication. The review excluded speculative and theoretical papers because it was important to ground our understanding of outcomes and impacts of using puppets in research evidence rather than in speculation.

Based on the literature review, it can be concluded that puppets are beneficial in education. Puppets should not only be nice products that perform in a well-prepared puppet show, but puppets should be integrated into various contexts to support learning. Therefore, we suggest that puppets should be integrated into teacher education. Teacher education should provide diverse possibilities to implement puppets in learning activities to make this media attractive for teacher students and their future students in schools.

\section{References}

Ahlcrona, M. (2012). The Puppet's Communicative Potential as a Mediating Tool in Preschool Education. International Journal of Early Childhood (IJEC), 44, 171-184.

Arasmo, A., \& Alopaeus, E. (1992). Nukketeatteri: opas elävään opetukseen. [Puppet theatre: A guide to powerful teaching] Tampere: Weilin+Göös. 
Aronoff, M. (2005). Puppetry as a therapeutic medium: An introduction. In M. Bernier \& J. O'Hare (Eds.), Puppetry in education and therapy (pp. 117-124). Bloomington, Indiana: Authorhouse.

Belfiore, C. (2013). Puppets Talk, Children Listen. How puppets are effective teaching aids for kids. TEACH Magazine, Jan/Feb 2013, 9-11.

Bennett, R. (2002). Teaching Reading with Puppets. ERIC Document Reproduction Service. Retrieved February 14, 2016, from ERIC database.

Bernier, M. (2005). Introduction to puppetry in therapy. In M. Bernier \& J. O'Hare (Eds.), Puppetry in education and therapy: Unlocking doors to the mind and heart (pp. 109-115). Bloomington, Indiana: AuthorHouse.

Brèdikytè, M. (2002). Dialogical Drama with Puppets (DDP) as a Method of Fostering Children's Verbal Creativity. In E. Majaron \& L. Kroflin (Eds.), The Puppet - What a Miracle! (pp. 33-60). Zagreb: the UNIMA Puppets in Education Commission.

Brits, J. S., Potgieter, A., \& Potgieter, M. J. (2014). Exploring the Use of Puppet Shows in Presenting Nanotechnology Lessons in Early Childhood Education. International Journal for Cross-Disciplinary Subjects in Education (IJCDSE), 5(4), 1798-1803.

Çağanağa, Ç., \& Kalmiş, A. (2015). The Role of Puppets in Kindergarten Education in Cyprus. Open Access Library Journal, 2, 1-9.

Debouny, E. (2002). Puppets as a teaching tool. In E. Majaron \& L. Kroflin (Eds.), The Puppet - What a Miracle! (pp. 53-58). Zagreb: the UNIMA Puppets in Education Commission.

Dunst, C. (2012). Effects of puppetry on elementary students' knowledge of and attitudes toward individuals with disabilities. International Electronic Journal of Elementary Education, 4, 451-457.

Dunst, C. (2014). Meta-Analysis of the Effects of Puppet Shows on Attitudes Toward and Knowledge of Individuals With Disabilities. Exceptional Children, 80(2), 136-148.

Evans, I., Harvey, S., Buckley, L. \& Yan, E. (2009). Differentiating classroom climate concepts: Academic, management, and emotional environments. Kōtuitui: New Zealand Journal of Social Sciences Online, 4(2), 131-146.

Fisler, B. (2003). Quantifiable Evidence, Reading Pedagogy, and Puppets. Research in Drama Education: The Journal of Applied Theatre and Performance, 8(1), 25-38. Retrieved March 14, 2016, from Teacher Reference Center database.

Gobec, D. (2012). Emotional-Social Curriculum of the Trnovo Model of Basic Learning Stimulated by a Puppet. In V. Geršak, H. Korošec, E. Majaron, \& N. Turnšek (Eds.), Promoting the Social Emotional Aspects of Education; A Multi-faceted Priority. Conference Proceedings. The 11th European Affective Education Network Conference 26th - 30th of June 2011 Ljubljana, Slovenia, 62-68.

Hackling, M., Smith, P. \& Murcia, K. (2011). Enhancing classroom discourse in primary science: The Puppets Project. Teaching Science, 57(2), 18-25.
Hamre, I. (2012). Affective Education through the Art of Animation Theatre. In L. Kroflin (Ed.), The Power of the Puppet (pp. 18-28). Zagreb, Croatia: Union Internationale de la Marionette.

Hannula, M. (2011). The structure and dynamics of affect in mathematical thinking and learning. In M. Pytlak, T. Rowland \& E. Swoboda (Eds.), Proceedings of the Seventh Congress of the European Society for Research in Mathematics Education. Poland: University of Rzeszów, 34-60.

Keogh, B., Naylor, S., Maloney, J., \& Simon, S. (2008). Puppets and engagement in science: a case study. Nordic Studies in Science Education, 4(2), 142-150.

Korošec, H. (2012). Playing with Puppets in Class-Teaching and Learning with Pleasure. In L. Kroflin (Ed.), The Power of the Puppet (pp. 29-45). Zagreb, Croatia: Union Internationale de la Marionette.

Korošec, H. (2013). Evaluating Study of Using Puppets as a Teaching Medium in Slovenian Schools. Šk. vjesn., 62, 4, 495-520.

Kroflin, L. (2012a). The role of the puppet in language teaching. In L. Kroflin (Ed.), The Power of the Puppet (pp. 46-62). Zagreb, Croatia: Union Internationale de la Marionette.

Kroflin, L. (2012b). The Role of the Puppet in Teaching a Second or Foreign Language at Workshops for Children. In V. Geršak, H. Korošec, E. Majaron, \& N. Turnšek (Eds.), Promoting the Social Emotional Aspects of Education; A Multi-faceted Priority. Conference Proceedings. The 11th European Affective Education Network Conference 26th - 30th of June 2011 Ljubljana, Slovenia, 109-114.

Laine, A., Ahtee, M., Näveri, L., Pehkonen, E., Portaankorva-Koivisto, P., \& Tuohilampi, L. (2015). Collective emotional atmosphere in mathematics lesson based on Finnish fifth graders' drawings. LUMAT, 3(1), 87-100.

Lowe, J., \& Matthew, K. (2000). Puppets \& Prose. Using puppets and children's literature in the science classroom. Science and Children, 37(8), 41-45.

Luckenbill, J. (2013). Circle Time Puppets. Teaching Social Skills. Teaching Young Children, 4(4), 9-11.

Maharani, S. (2016). The use of puppet: Shifting speaking skill from the perspective of students' self-esteem. Register Journal, 9(2), 101-126.?

Majaron, E. (2002). Puppets in the Child's Development. In E. Majaron \& L. Kroflin (Eds.), The Puppet - What a Miracle (pp. 47-52)! Zagreb: the UNIMA Puppets in Education Commission.

Mehrotra, S., Khunyakari, R., Natarajan, C., \& Chunawala, S. (2007). Collaborative learning in technology education: D\&T unit on puppetry in different Indian socio-cultural contexts. International Journal of Technology and Design Education, 19(1), 1-14.

Moriguchi, Y., Sakata, Y., Ishibashi, M. \& Ishikawa, Y. (2015). Teaching others rule-use improves executive function and prefrontal activations in young children. Frontiers in Psychology, 6(894), 1-9.

Peltonen, L., \& Tawast, M. (Eds.) (2009). Nukketeatteria suomalaisilla näyttämöillä. [Puppet theatre on Finnish stages] Keuruu: Otava. 
Piaget, J. (1962). Play, dreams and imitation in childhood. New York: Norton.

Remer, R., \& Tzuriel, D. (2015). "I Teach Better with the Puppet" - Use of Puppet as a Mediating Tool in Kindergarten Education - an Evaluation. American Journal of Educational Research, 3(3), 356-365.

Renfro, N. (1984). Puppetry, Language, and the Special Child. Austin: N. Renfro Studios.

Simon, S., Naylor, S., Keogh, B., Maloney, J., \& Downing, B. (2008). Puppets Promoting Engagement and Talk in Science. International Journal of Science Education, 30(9), 1229-1248.

Taras-Vaulasvirta, E. (2003). Nukke - tunteiden tulkki, kertojan kumppani. [Puppet - an interpreter of emotions, the narrator's partner] Helsinki: Lasten keskus.

Tilbrook, A., Dwyer, T., Reid-Searl, K., \& Parson, J. (2017). A review of the literature-The use of interactive puppet simulation in nursing education and children's healthcare. Nurse Education in Practice, 22, 73-79.

Torén, B. (1999). Handdockans möjligheter i förskolan och skolan. [Possibilities of the puppet in preprimary and primary school] Solna: Ekelunds förlag.

Vygotsky, L. S. (1962). Thought and Word. In L. Vygotsky, E. Hanfmann, \& G. Vakar (Eds.), Studies in communication. Thought and language (pp. 119-153). Cambridge, MA, US: MIT Press.

Whiteland, S. (2016). Exploring Aging Attitudes Through a Puppet Making Research Study. International Journal of Education \& the Arts, 17(3), 1-29. 